\title{
Board Capabilities and the Mediating Roles of Absorptive Capacity on Environmental Social and Governance (ESG) Practices
}

\author{
Aida Maria Ismail ${ }^{1}$, Zuria Hajar Mohd Adnan ${ }^{2}$, Fadzlina Mohd Fahmi ${ }^{1}$, Faizah Darus ${ }^{1} \&$ Colin Clark $^{3}$ \\ ${ }^{1}$ Faculty of Accountancy, Universiti Teknologi MARA, Puncak Alam Campus, Selangor, Malaysia \\ ${ }^{2}$ Finance Department, Times Media Sdn Bhd, Selangor, Malaysia \\ ${ }^{3}$ Faculty of Business and Law, Victoria University, Melbourne, Australia \\ Corresponddence: Aida Maria Ismail, Faculty of Accountancy, University Teknologi MARA, Puncak Alam Campus, \\ Selangor, Malaysia.
}

Received: April 20, 2019

Accepted: May 7, 2019

Online Published: May 19, 2019

doi:10.5430/ijfr.v10n3p11

URL: https://doi.org/10.5430/ijfr.v10n3p11

\begin{abstract}
Public listed companies in Malaysia have been pressured tremendously to accept the engagement of Environment, Social and Governance (ESG), but the engagement is still low based on previous studies. ESG will enhance company financial performance, image as well as the ability to attract and retain the workplace which contributes to the market value in the economy. This shows that ESG engagement improve company brand image and reputation, increase customer loyalty and sales as well as productivity. Corporate governance is seen to be the key role to ensure that companies engage with ESG practices since it can enhance the value creation and improve financial performance. Even the present investors are bound to look for non-financial performance elements like corporate governance and environmental, social and governance (ESG) practices that the company engaged since it is an evidence of effective corporate governance. Based on today's global and innovation-driven economy which also include social and environmental matters consisting of welfare distribution and growth, it is said that countries need to be more efficient in finding new ways to enhance the environmental policy promoting greater change and dynamics. Thus, they must find new ways to develop an innovation policy to emphasise the knowledge-driven economy on the capacity to adapt and adopt best practices, create, diffuse and transform innovation and knowledge. The absorptive capacity will recognise the ability of the individual and company in adopting the innovation which play an essential part in determining the characteristics of good corporate governance to ensure best ESG practices in the company. This paper examines the relationship between board capabilities and ESG practices through the mediating role of absorptive capacity. Board size, board diversity and board independent are the board capabilities that the paper investigates. Collection of information and data was from company's listed in FTSE4Good Bursa Malaysia from the year 2012 to 2016. The results from the regression analysis show that ESG practices have a significant relationship with board size, board diversity, board independence and absorptive capacity. On top of that, absorptive capacity is perceived to have influence on board diversity and board independence towards ESG practices. The results provide empirical evidence and guidance in identifying areas of problems in the current policy and amend it for a better policy in promoting sustainability.
\end{abstract}

Keywords: board capabilities, board size, board diversity, board independence, absorptive capacity and ESG practices

\section{Introduction}

Presently, investors act as a risk adverse and are more likely to invest at the lowest level of risk but expecting to get high returns. They are bound to look for non-financial performance elements like corporate governance and environmental, social and governance (ESG) practices that the company engaged. Sustainability initiatives consists of policies, projects and practices which companies use to achieve their goals and objectives (Matten \& Moon, 2008) and among the initiative is environmental, social and governance (ESG) practices. According to Said, Hj Zainuddin, and Haron (2009), Dato' Seri Najib Tun Razak, the former Prime Minister of Malaysia state that engagement with sustainability initiatives will enhance the company financial performance, image as well as the ability to attract and retain the workplace which contributes to the market value in the economy during the Corporate Social Responsibility Conference on 21 June 2004. This shows that companies that engage with sustainability initiatives 
tend to improve their brand image and reputation, increase their customer loyalty and sales as well as increase the product quality and productivity.

Since the 1980s, companies under the private sector in Malaysia have been pressured tremendously to accept the engagement of environmental, social and governance (ESG) but the level of the engagement is still low based on previous studies (Said et al., 2009). This may be due to the lack of effort from the top management to consistently ensure that their companies align with the ESG disclosure. Effective corporate governance would ensure the interest of their stakeholders would be looked after by the disclosure of the economic, social and environmental condition and performance (Haque, 2017; Said et al., 2009; Okon \& Richard 2017). The responsibility to monitor those tasks is on their top management by ensuring that there is an appropriate control system had been implemented (Said et al., 2009). A study from Matsumura, Prakash, and Vera-Muñoz (2013) stated that shareholders tend to pressure the managers of the companies to evaluate any opportunity and risk involved by the company towards the climate change and then report the financial consequences. Corporate governance is a key role to ensure that companies engage with ESG practices. This is because corporate governance is one of the factors that can enhance the value creation of the companies and improve their financial performance especially when these companies faced corporate scandals (Kakabadse, Ward, Korac-Kakabadse, \& Bowman, 2001; Shivdasani \& Zenner, 2004). Companies like Enron, Worldcom, Lechman Brothers and Rank Xerox are examples of companies which collapsed due to the bad corporate governance practices by the top management (Lawal, 2012). The takeaway from those incidents is that the ability of the firm to compete is determined by the firmness of governance mechanism especially in environmental circumstances (Lawal, 2012).

In addition, based on today's global and innovation-driven economy which also include social and environmental matters consisting of welfare distribution and growth, it is said that countries need to be more efficient in finding new ways to enhance the environmental policy promoting greater change and dynamics (Sysytem, 2005). Thus, they must find new ways to develop an innovation policy to emphasise the knowledge-driven economy on the capacity to adapt and adopt best practices, create, diffuse and transform innovation and knowledge (Jukneviciene, 2013; Okon, 2017). The absorptive capacity will recognise the ability of the individual and firms in adopting the innovation which play an essential part in determining the characteristics of good corporate governance to ensure best ESG practices in these companies.

\subsection{Problem Statement}

According to Bianchi, Drew, and Walk (2010), the development of ESG practices among companies had been acknowledged by the wold's financial markets as one of the principal factors, essential for the process of decision making by the investors. By considering the impact of these non-financial performances towards the financial performance, it will become the most important indicator for the investors. ESG practices has become the popular topic for the researchers as ESG can be used by the investors to analyse how companies run their businesses in an ethical manner which will become more important towards the ethical investors.

In recent years, the ESG performance has been an important issue in developing sustainable strategies which will affect the overall firm performance (Eccles, Serafeim, Seth, \& Ming, 2013). In addition, the relationship between ESG performance and financial performance has been studied extensively (Surroca, Tribó, \& Waddock, 2010). According to Friedman (2002), the company will entail additional cost which might reduce the value of the company if the social responsibility activities and environmental investments exceed the binding minimum standards of the company. However, according to Kim and Lyon (2015), the environmental regulatory paradigm is developed as enforcement to the firms to be aware of the environmental improvement because it will make them incur less profitable cost if they incur more environmental cost compared to the revenue incurred. Supporting that statement, it is said that ESG activities will enhance the value of the firms (M. Malik, 2014; Porter \& Kramer, 2011) as such activities can improve the capabilities of the management team and attract qualified employees to the firms (Ali Fatemi, 2017; Obodo \& Anigbata 2018) as well as strengthen the relationship between the stakeholders and enhance the reputation of the firms (Branco \& Rodrigues, 2006).

Stakeholders pay intention to the report of the company which not only focuses on the financial information of the company, but also emphasize the ESG disclosure regarding corporate social responsibility (CSR) metrics and sustainability (Nabil Tamimi, 2017). They added that CSR is being observed in the companies as companies become aware that their ethical labour practices, environmental reports and corporate governance are being watched by various stakeholders who will affect the performance and success of the companies. It is said that there is a need for the measurement and analysis of sustainability metrics as more firms tend to measure and disclose their sustainability performance (KPMG, 2011). 
In order to adapt with the ESG practices, countries around the globe needs to find new ways to innovate their policy work to ensure a knowledge-driven economy to build the capacity to adopt, adapt best global practices, create, diffuse as well as transform knowledge and innovation (Jukneviciene, 2013). This is because innovation will help an individual, organization and country to gain strengths and competitive advantages in their economic and social welfare. However, according to Dosi, Nelson, and Winter (2001), it is necessary for an organization to have organizational learning in order to reorganize their capabilities towards organizational change. As mentioned by Cohen and Levinthal (1990), absorptive capacity consists of two components which are: 1) the capacity to adopt the ideas from the outside world (adoption capacity) and 2) the capacity to make new inventions (invention capacity). Thus, the ability of the organization to create new capabilities depends on its ability to reconstruct and adapt the knowledge (Pettigrew \& Whipp, 1993). This is because, if the organizations do not have the ability to unlearn, it shows that the organization has lack of organizational capacity (Cohen \& Levinthal, 1990). However, according to Sarah E.A. Dixon (2007), in the transition economies, the absorptive capacity by the management is limited by their experience in different economic systems. Thus, it is important for the company to access the absorptive capacity of its board members to enhance the sustainability of the company. From the problem statement that was discussed earlier, the study examines the relationship between board capabilities and ESG practices through the mediating role of absorptive capacity.

\section{Literature Review}

The study explores the board capabilities consisting of board size, board diversity and board independence towards ESG practices as well as the mediating rule of absorptive capacity. The relationship between those board capabilities, absorptive capacity and ESG practices will be discussed in accordance with past literature review which has proven that there is a possible influence of board size, board diversity and board independence towards ESG practices. This would also include the possible mediating effect of absorptive capacity on the relationship between board capabilities and ESG practices. In addition, the theoretical framework is discussed based on the literature review.

\subsection{Dynamic Capabilities Theory}

The Dynamic Capabilities Theory is retrieved from the Capabilities Theory and the Resource-Based View created in the 1990s (Gonzalez-Campo, 2015). According to Eisenhardt and Martin (2000), this theory stated that the proposition of Resource and Capabilities Theory may be treated as static. This Dynamic Capabilities Theory can be considered as a new theory which tends to upgrade the explanation of capacity under the Resource-Based View and the Capabilities Theory by making the market dynamic in terms of competition as well as the acquisition of resources into their research (Gonzalez-Campo, 2015).

The reason behind the extension of the Resource and Capabilities Theory is that some researchers thought that the theory did not explain thoroughly how and why companies can have a competitive advantage, which was an unforeseeable change by previous studies (Eisenhardt \& Martin, 2000). According to Grant (1996), in a dynamic environment, dynamic capabilities of the management of the company will become sources for maintaining the competitive advantage and that management will find that knowledge has become critical resources for them to exploit. Hence, dynamic capabilities tend to lead the company to form their strategic company routines allowing the resources to be altered based on the acquisition, integration or recombination of the resources to create new strategic values (Grant, 1996; Pisano, 1994). Zollo and Winter (2002) stated that dynamic capabilities aligned with collective activity patterns would create and modify routines to generate greater organizational efficiency. To create and develop dynamic capabilities there will be three processes in the accumulation of experience and their routines, the articulation of the knowledge and codification of the knowledge. The existing organizational routines can be improved with the interaction of these three mechanisms. In the meantime, this interaction also allows the company to combine their tacit and explicit knowledge in the social process, which allows for the transmission of tacit knowledge that can promote creation, transfer, acquisition and integration of knowledge.

The function of Absorptive Capacity under dynamic capability is to be applied to its knowledge creation function that is essential for the development of new organizational capabilities (Todorova \& Durisin, 2007; Zahra \& George, 2002; Okon, 2018). These capabilities will be formed in the innovation development that will give advantage to the company to adapt with the changes within its surroundings.

\subsection{Resources and Capabilities Theory}

Gonzalez-Campo (2015) recommended that for a company to generate its competitive advantage, it should focus on resources and capabilities which are basic to the production of goods and services. Many researchers analyse a company's strength in exploiting resources and capabilities which could be presented as opportunities by the 
environment as well as to neutralize their external threats which can give a bad impact towards the performance of the company's productivity (Peteraf, 1993; Wernerfelt, 1984). This indicates that the company tends to focus on their competitiveness to achieve their profitability by showing their interest in their resources and capabilities. Thus, this condition made the development of Resources and Capabilities Theory as stated by Wernerfelt (1984), Barney (1991), Grant (1991), and Peteraf (1993) that is made with the assumption of heterogeneity in this resources and capability of the company with preferable skills to achieve their competitive advantages in the market.

According to Gonzalez-Campo (2015), under the Resources and Capabilities Theory, companies tend to possess extraordinary resources and capabilities leading to competitive advantages. Absorptive capacity allowed the users to apply their new knowledge to create the advantage (Wernerfelt, 1984). Based on Grant (1996) study, tacit knowledge is known as one of the key resources that can be considered as strategic resource and a skill that can be used to obtain primary capability to achieve competitiveness (Cohen \& Levinthal, 1990). According to Gonzalez-Campo (2015), under the development of Resources and Capabilities Theory, Absorptive Capacity is said to be part of the Dynamic Capabilities Approach. The approach is known as one of the knowledge absorption processes consisting of a series of phases like acquisition, assimilation, transformation and application that lead to the creation of new capabilities for the company (Zahra \& George, 2002).

\subsection{Environmental, Social and Governance (ESG) Practices}

The prevailing investment model focuses on the incorporation of environmental and social development in the global financial market (Cadman, 2011). ESG disclosure means the amount of environmental and social governance data that are voluntarily disclosed. ESG disclosure is an important indicator in identifying the ESG practices engaged in by the company as well as the essential variables that demonstrate how a company manages risks and monitors its ESG performance. Möller et al. (2015) found that companies that disclose much information on ESG tend to have lower capital costs. Companies report their ESG practices and performance in their annual reports in different ways, which contribute to difficulties in making comparisons. As such, a unified measure of the performance of ESG practices is needed (Möller et al., 2015; Obodo,2018). For investors to understand the risks and opportunities involved in the companies, the latter should organise their concepts of ESG disclosure to enable the former to access information regarding their ESG performance (Bassen \& Kovacs, 2008).

Investors use the disclosed information on ESG practices and performance to analyse the company's performance. A statically significant return of earnings is indicated when a company is involved in sin stock investments like gambling, tobacco and alcohol traded publicly (Hong \& Kacperczyk, 2009). However, the high abnormal returns from companies with bad ESG practices can also make investors reluctant to invest (Cadman, 2011). Realising the impact of ESG information on a company's security and reputation, most companies are developing better ways to disclose ESG. According to Murphy and McGrath (2013), the need for better ESG disclosures is due to legal concerns, such as lawsuits or penalties. Companies face challenges in disclosing their ESG practices. In any case, investors are able to integrate valuable company information in their decision-making process when ESG information is insufficient and inconsistent. By having good ESG practices and performance, the company can be protected whilst having substandard performance, because the ESG reputation will prevent the shareholder value from dropping. ESG information gives a good picture of the company to investors in terms of company transparency (Möller et al., 2015), accountability (Cadman, 2011) and ethical corporate and financial behaviour. Moreover, ESG practices and performance can effectively demonstrate the level of corporate compliance reflecting the company's future performance and sustainability.

\subsection{ESG Practices and Board Capabilities}

Corporate governance has a vital role in developing a company's management structure, which in turn, can improve cash flow and reduce the cost of capital. Tian and Twite (2011) reported an increase in the number of studies examining the relationship between corporate governance and company performance as well as the investor's interpretation of this relationship. Brown and Caylor (2009) found that the United States has good corporate governance as well as better ROE, ROA and Tobin's Q compared with other nations. Previous studies on the relationship between corporate governance and firm performance found that good firm performance can be developed by having good corporate governance. Thus, the development of the latter has favourable impact on the former. However, companies should also be wary of the costs associated with the implementation of an effective governance system. Most corporate governance studies seem to use the same variables to categorise the implementation of good corporate governance. These variables include board independence and size, CEO duality and ownership structure (Fooladi \& Nikzad Chaleshtori, 2011), managerial compensation, ownership structure, shareholder rights and board characteristics (Tian \& Twite, 2011). Board characteristics consist of board size, 
number of board meetings per year and percentage of independent directors, which are considered the most favourable variables in the United States (Eccles, Serafeim, \& Krzus, 2011).

According to Habbash, Xiao, Salama and Dixon (2014), the most essential element in corporate governance is the board of directors because they are closest to the management and shareholders. Thus, the board can reduce the separation of ownership and control. Moreover, the effective use of the board as an internal governance mechanism is essential in ensuring the performance and profitability of the firm (Bhagat \& Black, 1999; Brickley, Coles, \& Terry, 1994; Johnson, Daily, \& Ellstrand, 1996). In this sub-section, we review the theoretical foundation for the relationship between board size and diversity toward ESG practices.

\subsection{Hypotheses Development}

\subsubsection{Board Size}

Board size represents the total number of directors' seats in the corporate board. The size of the board has an impact on the independence of the board and the quality of corporate governance (Shivdasani \& Zenner, 2004). The company's board size is important in achieving effectiveness and in enhancing company performance. The board represents the ability to co-opt the resources limited from the external environment according to Kiel and Nicholson (2003). Dynamic capabilities theory can explain such a view. According to this theory, dynamic capabilities lead to competitive advantages as the management tends to exploit knowledge, which can be considered as a critical resource. Such knowledge can affect the board's corporate decision and the quality of the board members' deliberation. However, there is an ongoing debate in corporate governance literature with regards the ideal size of the board. According to Bennedsen, Kongsted and Nielsen (2008) the optimal size of the board can be based on many variables, such as firm size, age, industrial classification, degree of monitoring and value addition required by the members (Connelly \& Limpaphayom, 2004).

According to Guest (2009), board size has a negative relationship with company performance, which means that the larger the board size, the more negative the impact toward company performance. Jensen (1993) argued that a small board size has favourable impact on company performance, as the CEO could easily monitor the boards. The available literature presents two effects of board size: an increase in board size will decrease management board control as well as communication problems and coordination in management (Eisenberg, Sundgren, \& Wells, 1998; Jensen, 1993; Yermack, 1996). Moreover, Jensen (1993) added that a larger board room environment poses difficulties for the CEO to control the group, which could lead to poor decision making. This situation indicates that a larger board size could result in poor communication and coordination that, in turn, could affect the board's ability to make good decisions.

Several studies have been conducted to determine an ideal board size that could contribute to high performance. Jensen (1993) suggested seven or eight persons per board, whilst Lipton and Lorsch (1992) recommended an ideal board size consisting of eight or nine members. Meanwhile, other researchers favour a large size board that guarantees diversity; competitive advantage; a wide range of experiences, skills and expertise; corporate strategy, resource co-optation, creativity and innovation (C. M. Dalton \& Dalton, 2005; Jackling \& Johl, 2009; Klein, 2002). In other words, a larger board size guarantees that there would be more members, whose experiences can be used by the firms in effective decision making, especially when independent, outside directors are part of the board. Coles, McWilliams and Sen (2001) argue that a smaller board size will enhance company performance, as the researchers found that the larger board size will enhance the performance of a complex organisation. Therefore, the study formulates the following hypothesis:

H1: A significant relationship exists between large board size and ESG practices among the PLCs in Malaysia.

\subsubsection{Board Diversity}

A diverse board is a well-balanced board. Members of the board come from different backgrounds and professional fields, creating a synergy that can help members carry out their roles and duties (Carpenter \& Westphal, 2001). According to Kang, Cheng and Gray (2007) and Erhardt, Werbel and Shrader (2003), board diversity represents demographic elements like age, gender and ethnicity as well as cognitive elements like professionalism, experience and qualifications. Considering all the positive factors above, a well diverse board can enhance corporate fair play (D. Carter, D'Souza, Simkins, \& Simpson, 2007).

Another aspect of board diversity discussed nowadays is gender. Researchers are interested in exploring the roles of female directors in various perspectives (Haque, 2017), especially in their involvement in the social and environment context. Based on Huse and Grethe Solberg (2006), female directors are more involved, diligent and committed and are less self-oriented in making any decision for the company, thus enhancing the effectiveness of the board or its 
directors. Swartz and Firer (2005) highlighted the advantage of having females on the board as they possess a different sociological understanding and perception of matters that affect decision-making. These studies are supported by Hillman and Dalziel (2003), who explained the concept of resource-based view (RBV) theory on the board. In this instance, female board directors promote the carbon performance and the carbon-related strategies of a firm by having various aspects of the human and relational capital. This behaviour aligns with the study by Liao, Luo and Tang (2015) and Braun (2010), who all argued that female directors or managers show more concern for environmental issues compared to male directors or managers. Females are more likely to participate in environmental programs that would enable them to make contributions to social, environmental and sustainable development. Khlif, Hussainey and Achek (2015) argued for the advantages of having female directors, as firms that operate with high femininity tend to engage more on social and environmental programs to protect the interest of stakeholders. Furthermore, high gender diversity increases financial and social opportunities whilst promoting company legitimacy and success (Siboni et al., 2016; Olowa, 2018).

Although different attributes of board diversity tend to be investigated for the outcomes of the findings, the literature remains mixed and equivocal. Some studies have reported that board diversity is positively related to improving company performance (D. A. Carter, Simkins, \& Simpson, 2003; Erhardt et al., 2003; Richard, 2000; Roberson \& Park, 2007), whilst others found a negative and even no relationship in several instances (D. R. Dalton, Daily, Ellstrand, \& Johnson, 1998; Shrader, Blackburn, \& Iles, 1997; Zahra \& Stanton, 1988). Considering the numerous arguments on the presence of female directors on the board, we formulate the following hypothesis:

H2: A significant relationship exists between board diversity and ESG practices among the PLCs in Malaysia.

\subsubsection{Board Independence}

The board of directors is a crucial element in monitoring and supervising company management, and thus, independence of the board members has become a hotly debated issue among researchers. According to Eng and Mak (2003), independent directors should not have any financial relationship with the company; in other words, these directors should not own any shares in the company. Independent directors tend to show better decision-making, which leads to improved governance and supervision (Jensen, 1993). Currently, most organisations tend to have more independent directors on the board by increasing the number to only one or two inside directors on the board (Crespí-Cladera \& Pascual-Fuster, 2014). The above statement is supported by Bhagat and Black (2001), who argued that one of the principal duties of the board is to have independent directors who can effectively monitor the management of the company. Borokhovich, Parrino and Trapani (1996) supported this finding by stating that board independence could enhance company performance and value. Better supervision from the board can enhance the effectiveness of the management and improve company performance.

Based on agency theory, independent directors effectively monitor company management, thus enhancing company performance and reducing agency costs (De Villiers, Naiker, \& Van Staden, 2011). Independent directors are not involved in the daily operations of the company, and thus, they are less influenced by the executive management ((Liao et al., 2015). Hence, independent directors can provide effective monitoring management and relevant feedback to the company operation (Liao et al., 2015). This observation is also supported by dynamic capabilities theory, which states that this behaviour creates routines in the company to generate better organisational efficiency and effectiveness. Haque (2017) stated that in climate change activities of the company, the role of the board becomes critical in reducing agency cost, which might come in these two situations: CSR engagement in poor performing executives and long-term investment in carbon-related investment.

Inefficient directors or managers may display conflict of interest in completing their jobs, especially when they engage in social and environmental activities to maintain their relationship among the stakeholders and then use said relationships as an entrenchment strategy (Cespa \& Cestone, 2007). This behaviour is explained by Merkl-Davies and Brennan (2007), who stated that self-serving managers use this opportunity to manipulate poor company performance and decisions from the stakeholders. According to Haque (2017), underperforming directors tend to undertake ESG practices or initiatives like making donations to environmental NGOs and environmental pet projects and maintaining their relationships with environmental activists. Such actions are done by underperforming directors who want to leave a good impression on the stakeholders (Cordeiro \& Sarkis, 2008) and maintain their job position. This opportunistic act of ESG practices leads to a conflict of interest among the directors in performing their jobs.

According to Yasser, Entebang and Mansor (2015), there is an ongoing debate on the relationship between board independence and company performance which, some say, have no correlation at all. Sami, Wang and Zhou (2011) and Bonn (2004) found a significant positive relationship between percentage of independent board and company performance. However, S. U. Malik (2012) and Fooladi (2012) found no significant relationship between board 
independence and company performance, even though they expected a positive relationship based on literature. Mallin and Michelon (2011) stated that a company can have human and rational capital like competencies, unique skills, external links and professional expertise when it has independent directors. Independent directors resolve environmental difficulties, attract resources and manage any dependencies that could improve company performance. This idea is supported by O'Neill, Saunders and McCarthy (1989), who argued that independent directors use their experience and expertise to attract many environmental opportunities. A diverse set of independent directors are also capable of balancing environmental and financial accountability and meeting the company's short- and long-term objectives (Liao et al., 2015; Michelon \& Parbonetti, 2012). Thus, having independent directors could resolve the conflict of interest among directors and managers. Independent directors are more sensitive to stakeholder interest, which could lead to the innovative environmental activities (De Villiers et al., 2011). This strategy enhances the company image in the market and improves the reputation of the directors.

Studies from De Villiers et al. (2011) and Mallin and Michelon (2011) found a positive relationship between independent directors and social and environmental performance in US companies. Liao et al. (2015) also supported the above findings by arguing that a positive relationship exists between independent directors and social and environmental disclosure. Thus, this discussion leads to the following hypothesis:

H3: A significant relationship exists between board independence and ESG practices among the PLCs in Malaysia.

\subsubsection{Organizational Absorptive Capacity}

To adapt and adopt their capabilities, companies needs to consider the organisational learning proses as an essential strategy so that they are able to adapt the changes for a better future (Dosi et al., 2001; Eisenhardt \& Martin, 2000). Cohen and Levinthal (1990) have developed an organizational absorptive capacity to illustrate how a company absorbs relevant knowledge for its development. Absorptive capacity is known to give advantage to the company because it allows the company to identify the value of the new input or information which have been accumulated from internal and external sources and to absorb and apply the information for the decision-making in their business (Cohen \& Levinthal, 1990; Saraf, Liang, Xue, \& Hu, 2013). A number of researchers found that absorptive capacity played an important role in an information technology (IT) business literature when a company puts in enough effort to gain and internalize new IT knowledge (Joshi, Chi, Datta, \& Han, 2010; Malhotra, Gosain, \& Sawy, 2005). By having this absorptive capacity, a company can proactively conduct a quick and proper decision on their business strategies compared to their competitors (Elbashir, Collier, \& Sutton, 2011; Francalanci \& Morabito, 2008). In connection with Dynamic Capabilities Theory, absorptive capacity allows the user to exploit their knowledge to achieve the competitiveness of the company.

Additionally, absorptive capacity has been significant in certain areas like healthcare even though its dimensions are well-defined in other studies and its usefulness is quite established in many other contexts (Kash, Spaulding, Gamm, \& Johnson, 2013). There are three attributes of absorptive capacity identified by Cohen and Levinthal (1990), namely identification, assimilation and exploitation. However, the list of attributes has been expanded by other researchers to include the four attributes of acquisition, assimilation, transformation and exploitation of the new knowledge (Flatten, Engelen, Zahra, \& Brettel, 2011; Zahra \& George, 2002). Acquisition is the process of identifying valuable knowledge from internal resources. managerial compensation, ownership structure, shareholder rights and board characteristics (Lane \& Lubatkin, 1998). Assimilation reflects the process of understanding and interpreting the meaning of knowledge while transformation means integrating the new knowledge with current knowledge and then applying the knowledge (Zahra \& George, 2002). Finally, exploitation is the procedure of using the knowledge in improvising the company's performance and value ( $\mathrm{Wu} \& \mathrm{Hu}, 2012)$. Together, these four attributes will be able to confirm the company's ability to apply new knowledge. Prior researchers stated that high absorptive capacity led to better firm quality improvement (Kash et al., 2013; Lev, Fiegenbaum, \& Shoham, 2009; Wu \& Hu, 2012).

The company's capacity to utilize and exploit gained knowledge as part of the concept of re-conceptualization itself has been discussed by Minbaeva, Pedersen, Björkman, Fey, and Park (2003). Their study indicated that employees' motivation and ability are key factors for the development of the company's absorptive capacity. It also reveals that activities from the human resources management will have a positive influence on absorptive capacity development. An exploratory discussion on absorptive capacity development by Lenox and King (2004) found that managers will positively affect the absorptive capacity of the firm by giving important information to top management. Based on these arguments, a prominent level of absorptive capacity would enables organizations to transform data into insights that speed up the decision-making process and allow staff to respond quickly to customer needs. Therefore, we formulate the following hypothesis: 
H4: There is a significant relationship between absorptive capacity and ESG practices

\subsubsection{The Mediating Role of Absorptive Capacity}

Absorptive capacity can be considered as a higher-order organizational capability (Liu, Ke, Wei, \& Hua, 2013; Roberts, Galluch, Dinger, \& Grover, 2012) which enables company to identify, assimilate and exploit lower-order capabilities (e.g. operational capability and IT capability) in order to help companies acquire and maintain their competitive advantage (Cohen \& Levinthal, 1990; Grewal \& Slotegraaf, 2007; Zahra \& George, 2002). IT capabilities can be considered as lower-order capabilities that can be converted into higher-order capabilities (Pavlou \& El Sawy, 2010). There have been arguments regarding absorptive capacity acting as a complement towards IT capability in creating value for the company as well as increasing its performance. However, the performance of the company cannot be guaranteed unless the company has enough capacity to identify, absorb, transform as well as exploit the knowledge that IT has generated. Therefore, this condition proposes that engaging ESG practices through the mediating role of absorptive capacity has an indirect impact on the boards' capabilities as expressed by the following hypotheses:

H4a: Absorptive capacity mediates the relationship between board size and ESG practices

H4b: Absorptive capacity mediates the relationship between board diversity and ESG practices

H4c: Absorptive capacity mediates the relationship between board independence and ESG practices

\subsection{Theoretical Framework}

The theoretical framework represents the perception of the researchers on the relationship of variables to each other (model) and explains the reason on the association of these variables (theory). From the objectives of this study, it focuses on the ESG practices among the companies in Malaysia and the impact of board size, board diversity and board independence on those ESG practices. Apart from that, this study also tested the mediating effects of organizational absorptive capacity on the relationship between those board capabilities and ESG practices.

Figure 1 shows the theoretical framework for this study which proposes the association of dependent variable, independent variables and mediating variables.

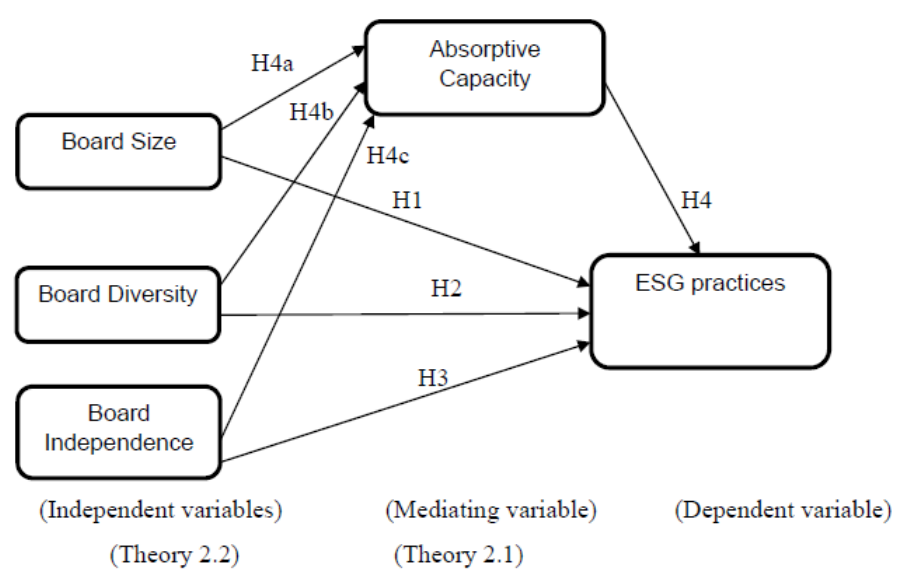

Figure 1. Theoretical framework of the relationship between board capabilities and ESG practices among the public listed companies in Malaysia and the mediating effect on that relationship

Based on the theoretical framework above, the objective of this study is to examine the relationship between board size, board diversity and board independence and ESG practices. According to the previous researcher's finding in the literature review earlier, the relationship in this study is expected to be a positive relationship between those board capabilities and ESG practices. As per this framework, previous studies found that capabilities of the board may affect the company's ESG practices. This theoretical framework also describes the association of organizational absorptive capacity mediating effects on the relationship of board capabilities and ESG practices among the companies. To this degree, based on the Resources and Capabilities Theory, a company will have a competitive advantage in the dynamic market if the management has a better knowledge regarding absorptive capacity to 
effectively and efficiently manage the resources and develop new opportunities for the company (Gonzalez-Campo, 2015).

\section{Research Methodology and Design}

The objective of this study is to analyse the ESG practices of Malaysian companies within five years of data collection. The study examines the relationship between board capabilities and the ESG practices of companies. Board capabilities consist of board size, diversity and independence. In addition, this study also aims to investigate the mediating effect of organizational absorptive capacity on the relationship between board capabilities and ESG practices. Thus, this section discusses the research design and methods conducted to fulfil the objectives of this study.

\subsection{Sample Description and Data Collection Procedure}

\subsubsection{Sample of ESG Companies}

To promote the sustainable practices among companies in Malaysia, Bursa Malaysia has taken various actions, such as implementing sustainability port and CSR guidelines (Russell, November 2016). Bursa Malaysia extended their effort in encouraging and supporting the companies to enhance ESG practices and disclosures by introducing the ESG index. The companies under FTSE4Good chosen as the FTSE4Good Malaysia Index constituents are selected from the top 200 Malaysian companies in FTSE Bursa Malaysia Emas Index. These constituents are screened by the Bursa Malaysia based on their transparency in defining ESG criteria. The developed index is assigned to identify Malaysian companies that exert more effort in corporate responsibility practices. The FTSE ESG Rating has become the engine of FTSE4Good Index. Thus, companies that wish to be listed in the FTSE4Good Index Constituents must pass the FTSE ESG Rating to obtain the specific threshold. The specific threshold will be the additional screen displayed in FTSE4Good Index Ground Rules. The rules of the FTSE ESG Rating are meant to give better understanding to the companies of practicing ESG in various aspects. The rating will provide investors flexible and granular data.

\subsubsection{Data Collection}

This study adopted the quantitative method that can be used in the descriptive hypotheses testing to determine the relationship of board capabilities on ESG practices. This study employed the cross-sectional method for the time considered, which was from September until November 2017. The main sources for this study included secondary data, consisting of information obtained from annual reports of the companies listed in the FTSE4Good based on the Bursa Malaysia website. Annual reports from 2012-2016 were used as references. Stratified sampling was applied in this study because the data were collected in separate groups from the Bursa Malaysia listing of companies. Stratified sampling generated a sample of the population that best represents the entire population of ESG practices among the PLCs in Malaysia. According to the June 2016 FSTE4Good list of companies, 34 companies registered in this group comprised the population of this study.

\subsection{Variables and Measurement}

Based on the research framework, the two variables used in this study were as follows: ESG practices as dependent variables, board capabilities as independent variables and absorptive capacity as the mediating variable. Board capabilities consist of board size, board diversity and board independence.

\subsubsection{Dependent Variable}

In this section, the dependent variables, namely, ESG practices among the companies that had been selected, was evaluated by using the metrics outlined by Nabil Tamimi (2017). The metrics were categorised in three groups: environmental, social and governance metrics.

Table 1. Examples of environmental metrics

\begin{tabular}{lll}
\hline Metric & Measurement items & Source \\
\hline ISO 14000 certification & Yes/No & 2017) \\
Energy efficiency policy & Yes/No \\
\cline { 2 - 2 } Environmental supply chain management & Yes/No \\
Green building policy & Yes/No \\
\hline
\end{tabular}


Sustainable packaging

Presence of environmental quality management policies

Protection of biodiversity (e.g. protection of trees, vegetation and wild life)

Climate change policies

\section{Yes/No}

Yes/No

Yes/No

Yes/No

Table 2. Examples of social metrics

\begin{tabular}{lll}
\hline Metric & Measurement items & Source \\
\hline Initiative employed to reduce social risks in the supply chain & Yes/No & (Nabil Tamimi, \\
\cline { 2 - 2 } Fair remuneration policy & Yes/No \\
Training initiatives & Yes/No \\
Commitment to equal opportunity policies & Yes/No \\
Childlabour prevention policies & Yes/No \\
Ethical policies & Yes/No \\
Whistle blower policies & Yes/No \\
\hline
\end{tabular}

Table 3. Examples of governance metrics

\begin{tabular}{lll}
\hline Metric & Measurement items & Source \\
\hline Number of female directors on company board & Count & (Nabil \\
\cline { 1 - 1 } Number of board meetings for the year & Count & \\
\cline { 1 - 2 } Number of meetings of the board's audit committee & Count & \\
\cline { 1 - 2 } Number of directors on the company's compensation committee & Count &
\end{tabular}

\subsubsection{Independent Variables}

In this section, the independent variables for board capabilities (board size, diversity and independence) were evaluated using the items outlined by Said et al. (2009) and Haque (2017)

Table 4. Operationalisation of independent variables

\begin{tabular}{lll}
\hline Independent variables & Measurement items & Source \\
\hline Board size & Number of directors sit on the board & (Said et al., 2009) \\
\hline Board diversity & $\begin{array}{l}\text { Dummy variable equals to 1 if there are females on board } \\
\text { and 0 otherwise }\end{array}$ & (Haque, 2017) \\
\hline Board independence & Percentage of independent directors on the board & (Haque, 2017) \\
\hline
\end{tabular}

\subsubsection{Mediating Variable}

In measuring the mediating variable, exploitation of the knowledge is being evaluated as outlined by Gonzalez-Campo (2015). Exploitation is one of the factors that can fulfil the goals of the company and satisfying its needs. This measurement is used to know the improvement of the existing competences, generate new competence as well as create new products (Cohen \& Levinthal, 1990). This measurement consists of a scale used by Gebauer, Worch, and Truffer (2012) that uses commercial application to acquire knowledge.

\section{$\mathrm{CAPAB}=\mathrm{EXPLOIT}$}

Where, EXPLOIT = measures the knowledge of exploitation by summing the variables consisting of the creation of new products or services and the enhancement of existing products or services as a total number of innovations in the 
company. The items involved are:

Table 5. Examples of exploitation metrics

\begin{tabular}{lll}
\hline Metric & Measurement items & Source \\
\hline $\begin{array}{l}\text { Innovation of the production } \\
\text { method }\end{array}$ & $\begin{array}{l}\text { Number of innovation implemented by } \\
\text { company }\end{array}$ & (Gonzalez-Campo, 2015) \\
\cline { 1 - 1 } $\begin{array}{l}\text { Improvement of the quality of } \\
\text { product or services }\end{array}$ & $\begin{array}{l}\text { Number of important innovation implemented } \\
\text { by company }\end{array}$ & $\begin{array}{l}\text { Number of important innovation implemented } \\
\text { by company }\end{array}$ \\
\hline $\begin{array}{l}\text { Broadening the product } \\
\text { services range }\end{array}$ & or
\end{tabular}

\subsection{Data Analysis}

The data collected for this study were recorded and analysed using Statistical Package for Social Sciences (SPSS) software Version 23 and Microsoft Excel. Descriptive analysis was conducted to examine the board size, diversity and independence as well as ESG practices to answer the study's main objective. To measure the mediating effect or absorptive capacity in the relationship between board capabilities and ESG practices, the correlation and regression will be carried out to the hypotheses. In this data analysis, the quantitative data and statistics demonstrated the relationship between the developed hypotheses. Linear regression is typically used to analyse the relationship between two variables, whilst multi-linear regression is used to analyse the relationship between multiple independent and dependent variables. The outcome of the regression analysis will be in terms of positive, negative and no correlation at all among the variables which had been tested. Positive correlation indicates that when one variables increase it will be similar with the other while negative correlation indicate the opposite reaction.

\section{Findings and Discussion}

In this section, data were collected and the results from tests and regressions were analysed. These results were analysed according to the reviewed literatures. Moreover, the data collected were transferred and analysed using SPSS software and Microsoft Excel. Thus, this step led to a better understanding of the relationship between corporate governance and ESG practices along with the mediating effect of absorptive capacity.

\subsection{Descriptive Statistics}

Table 6. Data descriptive statistics

\begin{tabular}{lllll}
\hline Variables & Mean & Maximum & Minimum & Std. Dev. \\
\hline ESG & 39.56 & 71 & 28 & 7.49 \\
\hline BODS & 9.24 & 17 & 5 & 2.18 \\
\hline BODD & 0.79 & 1 & 0 & 0.41 \\
\hline BODI & 48.58 & 90 & 11.11 & 15.84 \\
\hline CAPAB & 3.38 & 18 & 0 & 2.96 \\
$\mathbf{N}=\mathbf{1 7 0}$ & & & & \\
\hline
\end{tabular}

Descriptive statistics engaged with the variables covered the mean, median, maximum, minimum and standard deviation, which were determined by applying SPSS version 23. Based on Table 6, the descriptive statistic shows the result of all the variables used in this study across the period commencing from 2012 to 2016 among the companies listed as FTSE4Good constituents. Table 6 presents that the means score of the ESG practices is 39.56 and the standard deviation is 7.49. This shows that the companies that apply the ESG practices have the average of 39.56 . However, the highest value of ESG practices is $71 \%$ and the lowest value is $28 \%$.

For the independent variables of board size, the value of mean, maximum, minimum and standard deviation are 9.24, 17, 5 and 2.18 respectively. According to the table, the average board size is 9.24 which is larger than some of the literature reviews; Lipton and Lorsch (1992) recommended eight or nine while Jensen (1993) suggested seven or eight. The second independent variable is board diversity with a maximum value of $1 \%$ and minimum value of $0 \%$ of 
the companies. The standard deviation and mean score for board diversity are 0.41 and 0.79 respectively. The third independent variable is board independence which has a maximum of $90 \%$ and the minimum value is $11.11 \%$ of the companies. The mean and standard deviation for this variable are 48.58 and 15.84 respectively. The mediating variable is absorptive capacity has mean score at 3.38 and standard deviation at 2.96 . The maximum value of absorptive capacity is $18 \%$ and the minimum value is $0 \%$.

\subsection{Pearson Correlation Coefficient}

Table 7. Result of Pearson correlation coefficient

\begin{tabular}{lllllll}
\hline & & ESG & BODS & BODD & BODI & CAPAB \\
\hline ESG & Pearson Correlation & 1 & & & & \\
\hline BODS & Pearson Correlation & $.271^{* *}$ & 1 & & & \\
\hline BODD & Pearson Correlation & $.383^{* *}$ & $.236^{* *}$ & 1 & & \\
\hline BODI & Pearson Correlation & $.177^{*}$ & -.115 & -.009 & 1 & \\
\hline CAPAB & Pearson Correlation & $.359^{* *}$ & .090 & $.287^{* *}$ & .167 & 1 \\
\hline
\end{tabular}

** Correlation is significant at the 0.01 level (2-tailed)

* Correlation is significant at 0.05 level (2-tailed)

Pearson Correlation is applied to examine the concentration of the relationship between independent variables and dependent variables as well as the mediating variable. Table 7 presents the result of correlation for this study. The results present that all independent variables, dependent variable and mediating variable are consistently correlated toward each other. Based on Table 7, all the independent variables and mediating variable have significant correlation with the ESG practices among the companies. It means all the variables have significant influences towards to changes of ESG practices.

Furthermore, there is existence of a correlation between independent variables itself which is board size has significant correlation with board diversity. Besides this, there is only one independent variable which significantly influences the mediating variable which is board dependency. The variables were analysed using Pearson correlation which used to check the degree of multicollinearity between those variables. As shown in table 7, there is no coefficients that exceed 0.8 which means a good indicator. Thus, those variables do not have any multicollinearity problem Julie Pallant (2010). If there are any variables that are correlated, then the model of this study will be changed by taking into the account of this multicollinearity.

\subsection{Regression Analysis}

Table 8. Regression results of model

\begin{tabular}{llll}
\hline Variables & $\beta$ Coefficients & $\mathrm{t}$ & Sig. \\
\hline (Constant) & 23.355 & 8.211 & .000 \\
BODS & .705 & 2.971 & .003 \\
\hline BODD & 4.961 & 3.775 & .000 \\
\hline BODI & .077 & 2.398 & .018 \\
\hline CAPAB & .596 & 3.342 & .001 \\
\hline Adjusted $\mathrm{R}^{2}$ & .254 & & \\
\hline
\end{tabular}

After all the data were collected and tested by using regression model, the analysed data is shown in Table 8 . The table presents the effect of independent variable and mediating variable on the ESG practices among the companies. The result from the regression model indicates that the adjusted $\mathrm{R}^{2}=.254$, F $(170)=15.388, p<.5$. F-ratio is statistically significant at $5 \%$ level. The regression model contributes $25.4 \%$ of the variance in the ESG practices among the companies. The ESG practices have a significant relationship towards board size, board diversity, board independence as well as mediating variables when the results of the model obtain $p$ value equal to $.003, .000, .018$ and $.002(p<.05)$ respectively which indicate the significant relationship. Thus, this indicates that H1 (board size), H2 
(board diversity), H3 (board independence) and H4 (absorptive capacity) have been accepted as they have a significant positive influence on the ESG practices at level 5\%.

\subsubsection{Testing Mediation With Regression Analysis}

To test the mediating effect with the regression, the first step is to conduct regression analysis between independent variables and dependent variable. This step is to test the significant value between those variables.

Table 9. Regression analysis results with board size predicting ESG

\begin{tabular}{llll}
\hline Variables & $\beta$ Coefficients & $\mathrm{t}$ & Sig. \\
\hline (Constant) & 30.966 & 12.770 & .000 \\
BODS & .931 & 3.643 & .000 \\
\hline Adjusted $\mathrm{R}^{2}$ & .068 & & \\
\hline
\end{tabular}

Table 10. Regression analysis results with board diversity predicting ESG

\begin{tabular}{llll}
\hline Variables & $\beta$ Coefficients & $\mathrm{t}$ & Sig. \\
\hline (Constant) & 33.943 & 28.940 & .000 \\
BODD & 7.079 & 5.379 & .000 \\
\hline Adjusted $\mathrm{R}^{2}$ & .142 & & \\
\hline
\end{tabular}

Table 11. Regression analysis results with board independence predicting ESG

\begin{tabular}{llll}
\hline Variables & $\beta$ Coefficients & $\mathrm{t}$ & Sig. \\
\hline (Constant) & 35.510 & 19.358 & .000 \\
BODI & .083 & 2.324 & .021 \\
\hline Adjusted $\mathrm{R}^{2}$ & .025 & & \\
\hline
\end{tabular}

Table 9, Table 10 and Table 11 show board size, board diversity and board independence have significant effect toward ESG practices. This is because their significant values are $.000, .000$ and $.021(p<.05)$ respectively. The second step to test the mediation effect is by conducting regression analysis with independent variables to predict the mediating variable.

Table 12. Regression analysis results with board size predicting absorptive capacity

\begin{tabular}{llll}
\hline Variables & $\beta$ Coefficients & $\mathrm{t}$ & Sig. \\
\hline (Constant) & 2.255 & 2.272 & .024 \\
BODI & .122 & 1.166 & .245 \\
\hline Adjusted $\mathrm{R}^{2}$ & .002 & & \\
\hline
\end{tabular}

Table 13. Regression analysis results with board diversity predicting absorptive capacity

\begin{tabular}{llll}
\hline Variables & $\beta$ Coefficients & $\mathrm{t}$ & Sig. \\
\hline (Constant) & 1.714 & 3.563 & .000 \\
BODI & 2.101 & 3.890 & .000 \\
\hline Adjusted $\mathrm{R}^{2}$ & .077 & & \\
\hline
\end{tabular}


Table 14. Regression analysis results with board independence predicting absorptive capacity

\begin{tabular}{llll}
\hline Variables & $\beta$ Coefficients & $\mathrm{t}$ & Sig. \\
\hline (Constant) & 1.863 & 2.562 & .011 \\
BODI & .031 & 2.198 & .029 \\
\hline Adjusted $\mathrm{R}^{2}$ & .022 & & \\
\hline
\end{tabular}

Table 13 and Table 14 show that there is a significant relationship between board diversity and ESG practices. This is because the significant value of board diversity and board independence are .000 and $.029(p<.05)$ respectively. However, Table 12 presents that there is no relationship between board size and ESG practices as the significant value is $.245(p>.05)$. Thus, the mediating effect of absorptive capacity on the relationship between board size and ESG will not be conducted. According to MacKinnon, Fairchild, and Fritz (2007) if there is no significant relationship between independent variables and dependent variables, the mediating effect will not be analysed. The third step is conducting the regression analysis with ESG practices to predict the mediating variable.

Table 15. Regression analysis results with absorptive capacity predicting ESG

\begin{tabular}{llll}
\hline Variables & $\beta$ Coefficients & $\mathrm{t}$ & Sig. \\
\hline (Constant) & 36.499 & 44.644 & .000 \\
BODI & .906 & 4.979 & .000 \\
\hline Adjusted $\mathrm{R}^{2}$ & .123 & &
\end{tabular}

Based on Table 15, there is a significant relationship between absorptive capacity and ESG practices as the significant value is $.000(p<.01)$. The final step is to conduct the regression analysis with independent variables (board diversity and board independence) and mediating variable predicting dependent variable.

Table 16. Regression analysis results with board diversity and absorptive capacity predicting ESG

\begin{tabular}{llll}
\hline Variables & $\beta$ Coefficients & $\mathrm{t}$ & Sig. \\
\hline (Constant) & 32.769 & 27.896 & .000 \\
BODD & 5.642 & 4.265 & .000 \\
\hline CAPAB & .685 & 3.781 & .000 \\
\hline
\end{tabular}

Table 17. Regression analysis results with board independence and absorptive capacity predicting ESG

\begin{tabular}{llll}
\hline Variables & $\beta$ Coefficients & $\mathrm{t}$ & Sig. \\
\hline (Constant) & 33.916 & 19.223 & .000 \\
BODI & .057 & 1.650 & .101 \\
\hline CAPAB & .856 & 4.659 & .000 \\
\hline
\end{tabular}

Table 16 shows that the absorptive capacity has significant mediate on the relationship between board diversity and ESG practices and the significant value is $.000(p<.01)$. However, Table 17 presents that absorptive capacity has not significantly mediated the relationship between board independence and ESG practices as the significant value is .101 ( $p>.05)$.

\subsection{Summary}

Based on the results, none of the data used have violated the assumption, which allowed us to conduct the multiple regression test. The multiple regression tests answer the main objectives of this study which are to investigate the relationship between board capabilities and ESG practices and to examine the mediating effect of absorptive capacity 
on the relationship between board capabilities and ESG practices. The summary of the hypotheses results are illustrated in the Table 18.

Table 18. Summary of the result after the hypotheses testing

\begin{tabular}{ll}
\hline List of hypotheses & Results \\
\hline $\begin{array}{l}\text { H1: There is a significant relationship between large board size and ESG } \\
\text { practices among the public listed companies in Malaysia. }\end{array}$ & $\begin{array}{l}\text { Supported, } \\
\text { positive }\end{array}$ \\
\hline $\begin{array}{l}\text { H2: There is a significant relationship between board diversity and ESG } \\
\text { practices among the public listed companies in Malaysia. }\end{array}$ & $\begin{array}{l}\text { Supported, } \\
\text { positive }\end{array}$ \\
\hline $\begin{array}{l}\text { H3: There is a significant relationship between board independence and ESG } \\
\text { practices among the public listed companies in Malaysia. }\end{array}$ & $\begin{array}{l}\text { Supported, } \\
\text { positive }\end{array}$ \\
\hline $\begin{array}{l}\text { H4: There is a significant relationship between organizational absorptive } \\
\text { capacity and ESG practices among the public listed companies in Malaysia. }\end{array}$ & $\begin{array}{l}\text { Supported, } \\
\text { positive }\end{array}$ \\
\hline $\begin{array}{l}\text { H4a: Absorptive capacity mediates the relationship between large board size } \\
\text { and ESG practices. }\end{array}$ & $\begin{array}{l}\text { Not supported } \\
\text { H4b: Absorptive capacity mediates the relationship between board diversity } \\
\text { and ESG practices. }\end{array}$ \\
\hline $\begin{array}{l}\text { H4c: Absorptive capacity mediates the relationship between board } \\
\text { independence and ESG practices. }\end{array}$ & $\begin{array}{l}\text { Supported, } \\
\text { positive }\end{array}$ \\
\hline
\end{tabular}

\section{Conclusion}

In conclusion, this study reviewed the connection between corporate governance in terms of board capabilities which consists of board size, board diversity and board independence with the ESG practices among the selected companies. Additionally, this study also tested the mediating effect between absorptive capacity on the relationship between board capabilities and ESG practices. There are many studies on corporate governance and ESG practices which looked into the same factors, however many of them did not look into the sample of FTSE4Good of Bursa Malaysia and did not test the mediating effect of absorptive capacity. This study revealed impressive outcome like statistically significant relationship between board size, board diversity, board independence and absorptive capacity with ESG practices but absorptive capacity only mediates the relationship towards board diversity and board independence on ESG practices. This result supports the H1, H2, H3 and $\mathrm{H} 4$ hypotheses.

The significant relationship between board size and ESG practices indicates that the larger the board, size the better the performance of ESG practices in that organizations. This is due to the advantages of larger board size which consists of various backgrounds and experiences which can enhance the value of the company. Board size is an essential element for the company to enhance its value and performance as well as for the board of directors to improve their effectiveness. The significant relationship between board diversity and ESG practices means that the higher level of board diversity will give favourable impacts toward the ESG practices among the companies. This can be the reason for the participation of female directors in open discussions and decision-making during difficulties in CSR activities. Female directors tend to utilize their resources by making an investment in environmental activities to enhance their performance.

The significant relationship between board independence and ESG practices means that the higher level of independent directors in the board gives advantages to the companies in the ESG aspect. This is because independent directors are not involved in the daily operations of the company and they have no conflict of interest in practicing their rights as directors. Thus, the independent directors can effectively and efficiently monitor the performance of the board and company. The significant relationship between absorptive capacity and ESG practices show that the development of absorptive capacity will give a positive effect to the ESG practices among the company as by absorptive capacity, the company is able to acquire and exploit new knowledge for the effective ESG practices. Previous research findings found that the development of absorptive capacity motivate the staffs of the company to generate more value to the company. 
Since there is no significant relationship between board size and absorptive capacity, there will be no mediating effect of absorptive capacity towards the relationship of board size and ESG practices which does not support H4a. Then, based on the significant relationship between board diversity and absorptive capacity, there is partial mediation of the absorptive capacity towards the relationship between board diversity and ESG practices. To some extent, the relationship between board diversity and ESG practices remain significant even when absorptive capacity acts as a mediating variable.

Based on the significant relationship between board independence and absorptive capacity, there is partial mediation results of absorptive capacity to mediate the relationship between board independence and ESG practices. As the result, the relationship between board independence remains significant after absorptive capacity mediates the relationship.

This study contributes to the literature on the ESG practices among the PLCs in Malaysia by clearly demonstrating the relationship between ESG practices and corporate governance in terms of board size, diversity and independence. The study also provides some insight on the mediating effect between absorptive capacity on the relationship between board capabilities and ESG practices. Moreover, this study provides investors, NGOs and other stakeholders' effective indicators for better decision making in the social and environmental context. This contribution is significant, as the implementation of good corporate governance plays an essential role in determining the engagement of ESG practices of the company. Board capability is one of the areas in corporate governance that can contribute to the literature of determinants in ESG practices.

\section{Acknowledgements}

We would like to thank the Universiti Teknologi MARA, in collaboration with the Ministry of Education Malaysia (MOE), for providing the financial support under the Fundamental Research Grant Scheme (FRGS 600-IRMI/FRGS $5 / 3(073 / 2017))$. We are indeed very grateful for the grant, without which we would not be able to carry out the research.

\section{References}

Al-Matari, E. M., Al-Matari, Y. A., \& Saif, S. A. (2017). Ownership structure, audit quality and firm performance moderating and direct-effect models: An empirical study. Corporate Board: Role, Duties and Composition, 13(1), 28-35. http://doi.org/10.22495/cbv13i1p3

Bassen, A., \& Kovacs, A. M. M. (2008). Environmental, social and governance key performance indicators from a capital market perspective. Zeitschrift für Wirtschafts- und Unternehmensethik, 9(2), 182-192. https://doi.org/10.5771/1439-880X-2008-2-182

Bear, S., Rahman, N., \& Post, C. (2010). The impact of board diversity and gender composition on corporate social responsibility and firm reputation. Journal of Business Ethics, 97(2), 207-221. https://doi.org/10.1007/s10551-010-0505-2

Bhagat, S., \& Black, B. (1999). The uncertain relationship between board composition and firm performance. The Business Lawyer, 921-963.

Bhagat, S., \& Black, B. (2001). The non-correlation between board independence and long-term firm performance. Stanford Law and Economics Olin Working Paper No. 185.

Bianchi, R. J., Drew, M. E., \& Walk, A. N. (2010). On the responsible investment disclosure practices of the world's largest pension funds. Accounting Research Journal, 23(3), 302-318. https://doi.org/10.1108/10309611011092619

Bonn, I. (2004). Board structure and firm performance: Evidence from Australia. Journal of Management \& Organization, 10(1), 14-24. https://doi.org/10.1017/S1833367200004582

Borokhovich, K. A., Parrino, R., \& Trapani, T. (1996). Outside directors and CEO selection. Journal of Financial and Quantitative Analysis, 31(3), 337-355. https://doi.org/10.2307/2331395

Branco, M. C., \& Rodrigues, L. L. (2006). Corporate social responsibility and resource-based perspectives. Journal of Business Ethics, 69(2), 111-132. https://doi.org/10.1007/s10551-006-9071-z

Braun, P. (2010). Going green: women entrepreneurs and the environment. International Journal of Gender and Entrepreneurship, 2(3), 245-259. https://doi.org/10.1108/17566261011079233

Brickley, J. A., Coles, J. L., \& Terry, R. L. (1994). Outside directors and the adoption of poison pills. Journal of Financial Economics, 35(3), 371-390. https://doi.org/10.1016/0304-405X(94)90038-8 
Brooks, C. (2008). Introductory econometrics for finance. Cambridge University Press. https://doi.org/10.1017/CBO9780511841644

Brown, L. D., \& Caylor, M. L. (2009). Corporate governance and firm operating performance. Review of Quantitative Finance and Accounting, 32(2), 129-144. https://doi.org/10.1007/s11156-007-0082-3

Cadman, T. (2011). Re-Casting the Frame of Corporate Social Responsibility and Responsible Investment: An Environmental ans Social Perspective. https://doi.org/10.2139/ssrn.1975546

Campbell, J. L. (2007). Why would corporations behave in socially responsible ways? An institutional theory of corporate social responsibility. Academy of Management Review, 32(3), 946-967. https://doi.org/10.5465/amr.2007.25275684

Carpenter, M. A., \& Westphal, J. D. (2001). The strategic context of external network ties: Examining the impact of director appointments on board involvement in strategic decision making. Academy of Management Journal, 44(4), 639-660. https://doi.org/10.2307/3069408

Carter, D., D'Souza, F. P., Simkins, B. J., \& Simpson, W. G. (2007). The diversity of corporate board committees and firm financial performance. https://doi.org/10.2139/ssrn.972763

Cespa, G., \& Cestone, G. (2007). Corporate social responsibility and managerial entrenchment. Journal of Economics \& Management Strategy, 16(3), 741-771. https://doi.org/10.1111/j.1530-9134.2007.00156.x

Coles, J. W., McWilliams, V. B., \& Sen, N. (2001). An examination of the relationship of governance mechanisms to performance. Journal of Management, 27(1), 23-50. https://doi.org/10.1177/014920630102700102

Connelly, J. T., \& Limpaphayom, P. (2004). Environmental reporting and firm performance: evidence from Thailand. The Journal of Corporate Citizenship, (13), 137. https://doi.org/10.9774/GLEAF.4700.2004.sp.000015

Cordeiro, J. J., \& Sarkis, J. (2008). Does explicit contracting effectively link CEO compensation to environmental performance?. Business Strategy and the Environment, 17(5), 304-317. https://doi.org/10.1002/bse.621

Crespí-Cladera, R., \& Pascual-Fuster, B. (2014). Does the independence of independent directors matter?. Journal of Corporate Finance, 28, 116-134. https://doi.org/10.1016/j.jcorpfin.2013.12.009

Dalton, C. M., \& Dalton, D. R. (2005). Boards of directors: Utilizing empirical evidence in developing practical prescriptions. British Journal of Management, 16(s1), 91-97. https://doi.org/10.1111/j.1467-8551.2005.00450.x

Dalton, D. R., Daily, C., Ellstrand, A., \& Johnson, J. (1998). Board composition, leadership structure, and financial performance: Meta-analytic reviews and research agenda. Strategic Management Journal, 19(3), 269-290. https://doi.org/10.1002/(SICI)1097-0266(199803)19:3<269::AID-SMJ950>3.0.CO;2-K

De Villiers, C., Naiker, V., \& Van Staden, C. J. (2011). The effect of board characteristics on firm environmental performance. Journal of Management, 37(6), 1636-1663. https://doi.org/10.1177/0149206311411506

Eccles, R. G., Serafeim, G., \& Krzus, M. P. (2011). Market interest in nonfinancial information. Journal of Applied Corporate Finance, 23(4), 113-127. https://doi.org/10.1111/j.1745-6622.2011.00357.x

Eccles, R. G., Serafeim, G., Seth, D., \& Ming, C. C. Y. (2013). The Performance Frontier: Innovating for a Sustainable Strategy. Interaction. Harvard Business Review, 91(7), 17-18.

Eisenberg, T., Sundgren, S., \& Wells, M. T. (1998). Larger board size and decreasing firm value in small firms. Journal of Financial Economics, 48(1), 35-54. https://doi.org/10.1016/S0304-405X(98)00003-8

Eng, L. L., \& Mak, Y. T. (2003). Corporate governance and voluntary disclosure. Journal of Accounting and Public Policy, 22(4), 325-345. https://doi.org/10.1016/S0278-4254(03)00037-1

Erhardt, N. L., Werbel, J. D., \& Shrader, C. B. (2003). Board of director diversity and firm financial performance. Corporate Governance: An International Review, 11(2), 102-111. https://doi.org/10.1111/1467-8683.00011

Fatemi, A., Glaumb, M., \& Kaiser, S. (2017). ESG performance and firm value: The moderating role of disclosure. Global Finance Journal, 38, 45-64. https://doi.org/10.1016/j.gfj.2017.03.001

Fooladi, M. (2012). Board characteristics and firm performance. Journal of Modern Accounting and Auditing, 8(5), 688-694.

Fooladi, M., \& Nikzad Chaleshtori, G. (2011, June 17-19). Corporate governance and firm Performance. International Conference on Sociality and Economics Development (ICSED 2011), Kuala Lumpur, Malaysia. International Proceedings of Economics Development and Research (IPEDR) (vol.10). International 
Association of Computer Science and Information Technology Press (IACSIT Press), Singa

Friedman, M. (2002). The social responsibility of business is to increase its profits. Applied Ethics: Critical Concepts in Philosophy, 5, 57.

Guest, P. M. (2009). The impact of board size on firm performance: evidence from the UK. The European Journal of Finance, 15(4), 385-404. https://doi.org/10.1080/13518470802466121

Habbash, M., Xiao, L., Salama, A., \& Dixon, R. (2014). Are Independent Directors and Supervisory Directors Effective in Constraining Earnings Management?. Journal of Finance, Accounting and Management, 5(1), 125.

Haque, F. (2017). The effects of board characteristics and sustainable compensation policy on carbon performance of UK firms. The British Accounting Review, 49(3), 347-364. https://doi.org/10.1016/j.bar.2017.01.001

Hillman, A. J., \& Dalziel, T. (2003). Boards of directors and firm performance: Integrating agency and resource dependence perspectives. Academy of Management Review, 28(3), 383-396. https://doi.org/10.5465/amr.2003.10196729

Hong, H., \& Kacperczyk, M. (2009). The price of sin: The effects of social norms on markets. Journal of Financial Economics, 93(1), 15-36. https://doi.org/10.1016/j.jfineco.2008.09.001

Huse, M., \& Grethe Solberg, A. (2006). Gender-related boardroom dynamics: How Scandinavian women make and can make contributions on corporate boards. Women in Management Review, 21(2), 113-130. https://doi.org/10.1108/09649420610650693

Jackling, B., \& Johl, S. (2009). Board structure and firm performance: Evidence from India's top companies. Corporate Governance: An International Review, $\quad$ 17(4), https://doi.org/10.1111/j.1467-8683.2009.00760.x

Jensen, M. C. (1993). The modern industrial revolution, exit, and the failure of internal control systems. The Journal of Finance, 48(3), 831-880. https://doi.org/10.1111/j.1540-6261.1993.tb04022.x

Johnson, J. L., Daily, C. M., \& Ellstrand, A. E. (1996). Boards of directors: A review and research agenda. Journal of Management, 22(3), 409-438. https://doi.org/10.1177/014920639602200303

Kakabadse, A., Ward, K., Korac-Kakabadse, N., \& Bowman, C. (2001). Role and contribution of non-executive directors. Corporate Governance: The International Journal of Business in Society, 1(1), 4-8. https://doi.org/10.1108/EUM0000000005455

Kang, H., Cheng, M., \& Gray, S. J. (2007). Corporate governance and board composition: Diversity and independence of Australian boards. Corporate Governance: An International Review, 15(2), 194-207. https://doi.org/10.1111/j.1467-8683.2007.00554.x

Khlif, H., Hussainey, K., \& Achek, I. (2015). The effect of national culture on the association between profitability and corporate social and environmental disclosure: a meta-analysis. Meditari Accountancy Research, 23(3), 296-321. https://doi.org/10.1108/MEDAR-12-2014-0064

Kiel, G. C., \& Nicholson, G. J. (2003). Board composition and corporate performance: How the Australian experience informs contrasting theories of corporate governance. Corporate Governance: An International Review, 11(3), 189-205. https://doi.org/10.1111/1467-8683.00318

Kim, E.-H., \& Lyon, T. P. (2015). Greenwash vs. Brownwash: Exaggeration and Undue Modesty in Corporate Sustainability Disclosure. Organization Science, 26(3), 705-723. https://doi.org/10.1287/orsc.2014.0949

Klein, A. (2002). Audit committee, board of director characteristics, and earnings management. Journal of Accounting and Economics, 33(3), 375-400. https://doi.org/10.1016/S0165-4101(02)00059-9

Kock, C. J., Santaló, J., \& Diestre, L. (2012). Corporate governance and the environment: what type of governance creates greener companies?. Journal of Management Studies, 49(3), 492-514. https://doi.org/10.1111/j.1467-6486.2010.00993.x

KPMG. (2011). Corporate sustainability: A progress report. KPMG International London, UK.

Lawal, B. (2012). Board dynamics and corporate performance: review of literature, and empirical challenges. International Journal of Economics and Finance, 4(1), 22. https://doi.org/10.5539/ijef.v4n1p22

Liao, L., Luo, L., \& Tang, Q. (2015). Gender diversity, board independence, environmental committee and greenhouse gas disclosure. The British Accounting Review, 47(4), 409-424. 
https://doi.org/10.1016/j.bar.2014.01.002

Lipton, M., \& Lorsch, J. W. (1992). A modest proposal for improved corporate governance. The Business Lawyer, 59-77.

Malik, M. (2014). Value-Enhancing Capabilities of CSR: A Brief Review of Contemporary Literature. Journal of Business Ethics, 127(2), 419-438. https://doi.org/10.1007/s10551-014-2051-9

Malik, S. U. (2012). Relationship between corporate governance score and stock prices: Evidence from KSE-30 index companies. International Journal of Business and Social Science, 3(4).

Mallin, C. A., \& Michelon, G. (2011). Board reputation attributes and corporate social performance: An empirical investigation of the US best corporate citizens. Accounting and Business Research, 41(2), 119-144. https://doi.org/10.1080/00014788.2011.550740

Matsumura, E. M., Prakash, R., \& Vera-Muñoz, S. C. (2013). Firm-value effects of carbon emissions and carbon disclosures. The Accounting Review, 89(2), 695-724. https://doi.org/10.2308/accr-50629

Matten, D., \& Moon, J. (2008). "Implicit" and "explicit" CSR: A conceptual framework for a comparative understanding of corporate social responsibility. Academy of Management Review, 33(2), 404-424. https://doi.org/10.5465/amr.2008.31193458

Merkl-Davies, D. M., \& Brennan, N. M. (2007). Discretionary disclosure strategies in corporate narratives: incremental information or impression management?. Journal of Accounting Literature, 27, 116-196.

Michelon, G., \& Parbonetti, A. (2012). The effect of corporate governance on sustainability disclosure. Journal of Management \& Governance, 16(3), 477-509. https://doi.org/10.1007/s10997-010-9160-3

Möller, V., Koehler, D. A., \& Stubenrauch, I. (2015). Finding the Value in Environmental, Social and Governance Performance New Perspectives on Corporate Social Responsibility, pp. 275-283. Springer. https://doi.org/10.1007/978-3-658-06794-6_14

Murphy, D., \& McGrath, D. (2013). ESG reporting-class actions, deterrence, and avoidance. Sustainability Accounting, Management and Policy Journal, 4(2), 216-235. https://doi.org/10.1108/SAMPJ-Apr-2012-0016

Nabil Tamimi, R. S. (2017). Transparency among S\&P 500 companies: an analysis of ESG disclosure scores. Management Decision, 55(8), 1660-1680. https://doi.org/10.1108/MD-01-2017-0018

Obodo, N. A. (2018). Content Analysis of Time Management as a Tool for Corporate Effectiveness. International Journal of Applied Economics, Finance and Accounting, 2(2), 36-39. https://doi.org/10.33094/8.2017.2018.22.36.39

Obodo, N. A., \& Anigbata, D. O. (2018). Challenges of Implementing Electronic Governance in Public Sector Organizations in Nigeria. International Journal of Applied Economics, Finance and Accounting, 2(1), 30-35. https://doi.org/10.33094/8.2017.2018.21.30.35

Okon, E. O., \& Richard, S. H. (2017). Gender and Transport Sector Employment: Evidence from Kogi State, Nigeria. American Journal of Education and Learning, 2(1), 1-13. https://doi.org/10.20448/804.2.1.1.13

Okon, P. E. (2017). Name as a Vehicle of Communication: A Case of the Efiks of Nigeria's Cross River State. International Journal of English Language and Literature Studies, 6(2), 33-41. https://doi.org/10.18488/journal.23.2017.62.33.41

Okon, P. E. (2018). Comparative Analysis of Mass Media Coverage of the Fight Against Corruption in Nigeria by the Obasanjo and Buhari Administrations. International Journal of Emerging Trends in Social Sciences, 4(2), 47-57. https://doi.org/10.20448/2001.42.47.57

Olowa, O. W. (2018). Determinants of Rural Residential Solid Waste Collection Services in Lagos State. International Journal of Sustainable Development \& World Policy, 7(1), 1-7. https://doi.org/10.18488/journal.26.2018.71.1.7

O'Neill, H. M., Saunders, C. B., \& McCarthy, A. D. (1989). Board members, corporate social responsiveness and profitability: Are tradeoffs necessary?. Journal of Business Ethics, 8(5), 353-357. https://doi.org/10.1007/BF00381726

Pallant, J. (2005). SPSS Survival Manual: a Step by Step Guide to Data Analysis Using SPSS (Version 12, 2nd ed.). UK (2005): Open University Press. 
Pallant, J. (2010). SPSS survival manual: A step by step guide to data analysis using SPSS. Maidenhead: Open University Press/McGraw-Hill.

Porter, M. E., \& Kramer, M. R. (2011). The big idea: Creating shared value. Harvard Business Review, 89(1), 2.

Richard, O. C. (2000). Racial diversity, business strategy, and firm performance: A resource-based view. Academy of Management Journal, 43(2), 164-177. https://doi.org/10.2307/1556374

Roberson, Q. M., \& Park, H. J. (2007). Examining the link between diversity and firm performance: The effects of diversity reputation and leader racial diversity. Group \& Organization Management, 32(5), 548-568. https://doi.org/10.1177/1059601106291124

Russell, F. (2016, November). FAQ-FTSE4 Good Bursa Malaysia.

Said, R., Hj Zainuddin, Y., \& Haron, H. (2009). The relationship between corporate social responsibility disclosure and corporate governance characteristics in Malaysian public listed companies. Social Responsibility Journal, 5(2), 212-226. https://doi.org/10.1108/17471110910964496

Salkind, N. J. (2004). Statistics for people who (think they) hate statistics. SAGE Publications, Inc.

Sami, H., Wang, J., \& Zhou, H. (2011). Corporate governance and operating performance of Chinese listed firms. Journal of International Accounting, Auditing and Taxation, 20(2), 106-114. https://doi.org/10.1016/j.intaccaudtax.2011.06.005

Shivdasani, A., \& Zenner, M. (2004). Best practices in corporate governance: what two decades of research reveals. Journal of Applied Corporate Finance, 16(2-3), 29-41. https://doi.org/10.1111/j.1745-6622.2004.tb00536.x

Shrader, C. B., Blackburn, V. B., \& Iles, P. (1997). Women in management and firm financial performance: An exploratory study. Journal of Managerial Issues, 355-372.

Siboni, B., Siboni, B., Sangiorgi, D., Sangiorgi, D., Farneti, F., Farneti, F., ... de Villiers, C. (2016). Gender (in) accounting: insights, gaps and an agenda for future research. Meditari Accountancy Research, 24(2), 158-168. https://doi.org/10.1108/MEDAR-04-2016-0054

Surroca, J., Tribó, J. A., \& Waddock, S. (2010). Corporate responsibility and financial performance: The role of intangible resources. Strategic Management Journal, 31(5), 463-490. https://doi.org/10.1002/smj.820

Swartz, N., \& Firer, S. (2005). Board structure and intellectual capital performance in South Africa. Meditari Accountancy Research, 13(2), 145-166. https://doi.org/10.1108/10222529200500017

Sysytem, G. o. I. (2005). Volume 1: Synthesis Reprt. Retrieved from https://www.scribd.com/document/7145178/Governance-of-Innovation-Systems

Tian, G. Y., \& Twite, G. (2011). Corporate governance, external market discipline and firm productivity. Journal of Corporate Finance, 17(3), 403-417. https://doi.org/10.1016/j.jcorpfin.2010.12.004

Ul-Islam, T. (2011). Normality testing-A new direction. International Journal of Business and Social Science, 2(3).

Yasser, Q. R., Entebang, H. A., \& Mansor, S. A. (2015). Corporate governance and firm performance in Pakistan: The case of Karachi Stock Exchange (KSE)-30. https://doi.org/10.2139/ssrn.2551636

Yermack, D. (1996). Higher market valuation of companies with a small board of directors. Journal of Financial Economics, 40(2), 185-211. https://doi.org/10.1016/0304-405X(95)00844-5

Zahra, S. A., \& Stanton, W. W. (1988). The implications of board of directors composition for corporate strategy and performance. International Journal of Management, 5(2), 229-236. 